\title{
TRABZON İMÂRET-İ HATUNIYY VAKFI VE GELİRLERİ (1550-1650)
}

Sebahittin USTA*

\section{ÖZ}

Trabzon'daki mevcut vakıflar içerisinde sahip olduğu gelirleriyle birlikte şehrin sosyal ve iktisadi hayatı içerisinde önemli bir yere sahip olan en büyük vakıf, İmâret-i Hatuniye Vakfi'dır. Trabzon'da bugün mevcut olan Gülbahar Hatun Camii ve türbesinden başka imâret, medrese, mekteb, darü'l-kurra, misafirhane, aşhane, firın, kiler, mahzen ve ahırdan oluşan Hatuniye Külliyesi, Yavuz Sultan Selim'in annesi Gülbahar Hatun adına yaptırılmıştır. Hatuniye imâreti olarak bilinen bu külliyenin inşaatının 1514-1515'te tamamlandığı anlaşılmaktadır. Külliyenin adının geçtiği bilinen ilk belge Trabzon'a ait 1553 tarihli Tahrir Defteri'dir. Bu defterde "İmâret-i Hatuniye" adıyla mahalleye rastlanmakta ve aynı tarihteki "haric ez-defter" kaydından yeni kurulduğu anlaşılmaktadır. Mahallenin 1562 tarihli Trabzon Şeriye Sicili'nde "İmâret-i Amire" ve 1583 tarihli tahrirde "Cami-i İmâret-i Amire-i Hatuniye" adıyla zikredildiği görülmektedir. Mahallenin surun hemen dışında batı varoşlarında olduğu anlaşılmaktadır. Vakfin gelirlerini tarımsal sahaları oluşturan cibâyetler, bedesten, hamam, arazi, bahçe, zemin mukataalan, boyahane ve değirmenler teşkil etmektedir.

Anahtar Sözcükler: Trabzon, Vakıf, İmâret-i Hatuniye, Gelir, Cibâyet

\section{THE WAQF TRABZON IMÂRET-İ HATUNIYE AND ITS SOURCES OF INCOME}

\begin{abstract}
Thanks to its sources of income, The Waqf İmâret-i Hatuniye is the largest waqf which has an important position for the social and financial life in the Trabzon. Gülbahar Hatun Mosque, still present in Trabzon, its tomb and Hatuniye Islamic-social complex which includes imaret, madrasa, school, dar'ul kurra, guest house, kitchen, storeroom, bakeshop, barn were built in the name of Gülbahar Hatun, the mother of Yavuz Sultan Selim. This islamic-social complex, Imâret-i Hatuniye, is considered to be constructed between the years of 1514-1515. It is known that the name of this complex was first seen in the Cadastral Record book of 1553. A neighborhood called as İmâret-i Hatuniye was recorded in this book and it was inferred from the recordings of "haric ezdefter" that it was newly built then. It is seen that this neighborhood was called
\end{abstract}

Dr. Öğr. Gör., KTÜ, Edebiyat Fakültesi Tarih Bölümü, TRABZON. s.usta@ktu.edu.tr 
as "İmâret-i Amire" in Trabzon court records of 1562 and "Cami-i İmâret-i Amire-i Hatuniye" in the Cadastral Record book of 1583. It is also understood that this neighborhood was located outside of the city walls, in the western outskirts of the city. Among the sources of this waqf's income were collections of agricultural fields, covered bazaar, public bath, dyehouse, mills, and muqata'ah for estate, yard and ground.

Keywords: Trabzon, Income of Vaqf, İmâret-i Hatuniye, , Cibâyet

\section{Giriş}

Trabzon'un en büyük vakfı olan Hatuniye Vakfı'na ait bütün gelirlerin ve harcamaların tespit edilebilmesi, kaynakların yetersiz olması sebebiyle mümkün gözükmemektedir. 16. yüzyıla ait tahrir defterleri ve şeriye sicillerine çeşitli vesilelerle yansıyan kayıtlar, vakfın gelirleriyle ilgili bir kısım bilgiler vermektedir. Bu yüzyıla ait Trabzon Şeriye Sicilleri'nin büyük çoğunluğunun günümüze ulaşmaması, her yıla ait verilere ulaşmayı engellemektedir. Vakfın gelir ve giderleriyle ilgili 17. yüzyılın ilk yarısına ait Maliyeden Müdevver Defterlerdeki muhasebe kayıtları dikkate alınarak yapılan bir çalışma, önemli bilgiler ihtiva etmektedir. ${ }^{1}$ Diğer taraftan bu döneme ait şeriye sicilleri ve arşiv belgeleri de vakfın gelirleriyle ilgili bir takım bilgiler vermektedir. Öncelikle tahrir defterlerindeki bilgilerle muhasebe kayıtlarını ihtiva eden çalışmaya ait veriler aktarılacak ve diğer arşiv belgelerinde rastlanan bilgilerle gelir kalemleri ifade edilecektir.

Vakfın gelirleriyle ilgili olarak 1515-1532 tarihlerini ihtiva eden 53 numaralı Tımar İcmal Defteri'nde şu bilgilere rastlanmaktadır: Hatuniye Evkafi'na ait Bedesten'in yıllık geliri 6.322 akçe, Saray-1 Amire civarındaki Çifte Hamam adıyla anılan hamamın kirası 5.863 akçe, Tekfur Çayırı'ındaki hamamın kirası 4000 akçe, Bedesten yanındaki zeytinliğin mukataası 300 akçe, Değirmenderesi Köprüsü yanındaki 6 göz değirmenin kirası 12.000 akçe, Tekfur Çayırı'ndaki saraydan Çelebi Sultan Sarayı'na kadar uzanan zeminlerin mukataası 1.000 akçe, Tekfur Çayırı'ndaki bahçenin mukataası 1.000 akçe, Faroz bahçesi, çayırlık, yoncalık ve 124 göz dükkânı ile birlikte toplam y1llı gelirinin 39.760 akçe olduğu görülmektedir. ${ }^{2} 1518$ tarihli kayitları ihtiva eden 1 numaralı Tımar Zeamet Tevcih Defteri'nde yer alan ve sonradan eklendiği anlaşılan Muharrem 928 (Aralık 1521) tarihli bir kayda göre, Trabzon şehrine ait boyahane mukataasının (7.000 akçe) daha önceden şehirdeki İmâret-i Hatuniye'ye vakf olunduğu ve bunun geri alınarak sancak

1 Kayhan Orbay, "The Impreial Waqf of Hatuniyye in Trabzon 1024-75/1615-1665”, Osmanl Öncesi ve Osmanl Araştırmalar Uluslararası Komitesi XVII. Sempozyumu Bildirileri, Trabzon 2011, s.441-450.

$2 B O A$, TD, nr. 53, s. 3. 
beyi gelirlerine ilave edildiği görülmektedir. ${ }^{3}$ Yine bu defterde Akçaabat nahiyesindeki kasaphane ve kervan zeminlerinden alınan vergilerden başka elde edilen gelirin Hatuniye Vakfi'na ait olduğu anlaşılmaktadır. ${ }^{4}$ Ayrıca İstanbul'da Sultan Bayezid Camii yanındaki yeni hamamın mukataası da senede 75.000 akçe düzeyindedir. ${ }^{5}$

Trabzon Sancağına ait 1583 tarihli tahrirde vakfin gelirleri şu şekilde gösterilmektedir: İmâretin yakınındaki hamam ve dükkânlarının mukataası 10.000 akçe, Ortahisar'daki hamamın mukataası 5.833 akçe, Pazar-1 Siyah da denilen Bedesten'in geliri 5.000 akçe, değirmenlerin geliri 4.000 akçe, İmâretin yakınındaki dükkânların haricindeki 115 göz dükkânın kirası 14.724 akçe ve vakfa ait çayırların, bahçelerin, zeminlerin ve yoncalıkların toplam yıllık geliri 45.842 akçedir. ${ }^{6}$

İmâret-i Hatuniye Vakfi'nın gelirleriyle ilgili yapılan bir çalışmada, vakfin 1615-1646 yılları arasındaki gelir ve harcamalarına ait muhasebe kayıtları da mevcuttur. Bu kayıtlardaki veriler aşağıdaki tablodaki gibidir:

Tablo 1: Trabzon Hatuniye Vakfi'nda Temel Gelir ve Giderler

\begin{tabular}{|l|c|c|c|c|c|c|c|c|c|c|c|c|c|}
\hline & 1615 & 1616 & 1618 & 1619 & 1622 & 1629 & 1634 & 1635 & 1636 & 1642 & 1643 & 1644 & 1646 \\
\hline Toplam Gelir & $782.210 \mathrm{a}$. & 812.969 & 601.518 & 226.074 & 632.141 & 483.586 & 469.146 & 350.760 & 251.135 & 498.972 & 497.659 & 570.846 & 589.642 \\
\hline $\begin{array}{l}\text { Bir Önceki } \\
\text { Yuldan Kalan } \\
\text { Bakiye }\end{array}$ & 126.625 & 131.976 & 30.670 & 0 & 76.953 & 94.830 & 129.427 & 11.265 & 0 & 67.144 & 87.754 & 110.689 & 156.844 \\
\hline Güncel Gelirler & 635.585 & 615.493 & 570.848 & 48.232 & 531.722 & 330.493 & 341.339 & 339.495 & 251.135 & 396.828 & 388.895 & 415.157 & 432.798 \\
\hline Toplam Gider & 662.613 & 321.164 & 452.828 & 197.414 & - & 330.493 & 439.861 & 305.952 & 246.035 & 387.178 & 388.989 & 376.651 & 391.798 \\
\hline Maaşlar & 188.520 & 184.650 & 178.940 & 70.110 & - & 294.540 & 227.955 & 156.465 & 110.125 & 208.600 & 232.900 & 187.120 & 213.375 \\
\hline Harcamalar & 474.093 & 136.514 & 273.888 & 122.354 & 51.338 & 35.953 & 61.696 & 37.707 & 61.500 & 165.918 & 156.689 & 189.531 & 178.423 \\
\hline $\begin{array}{l}\text { Mutfak } \\
\text { Harcamaları }\end{array}$ & 430.320 & 100.537 & 220.792 & 113.452 & - & - & 150.510 & 111.780 & 74.410 & 12.660 & 132.340 & 141.626 & 113.423 \\
\hline $\begin{array}{l}\text { Muhtelif } \\
\text { Harcamalar ve } \\
\text { Tamir Giderleri }\end{array}$ & 31.799 & 34.193 & 43.957 & 7.305 & - & 19.824 & 43.283 & 29.303 & 10.712 & 120.682 & 15.522 & 26.470 & 32.144 \\
\hline Diğer Giderler & - & 309.347 & 86.249 & 23.460 & 212.627 & 30.000 & 18.020 & 0 & 0 & 24.000 & 24.000 & 74.019 & 24.000 \\
\hline $\begin{array}{l}\text { Tahsil } \\
\text { Edilemeyen } \\
\text { Gelir }\end{array}$ & 131.976 & 179.466 & 62.790 & 2.177 & 310.739 & 115.145 & 11.265 & 44.107 & 1.170 & 86.864 & 110.689 & 128.949 & 179.074 \\
\hline Kalan & 12.379 & 2.992 & 0 & 3.023 & - & 7.950 & 0 & 638 & 3.930 & 930 & -26.019 & -8.733 & -5.230 \\
\hline
\end{tabular}

Kaynak: Kayhan Orbay, "The Imperial Waqf of Hatumiyye in Trabzon (1615-1665)", Osmanlı Öncesi ve Osmanlı Araştırmalan Uluslararast Komitesi 17. Sempozyumu Bildirileri, s. 449.

Vakfin 1615 'te bütün gelirlerinin 782.212 akçe olduğu görülmektedir. Ancak bu miktar, vakfın bütün akarlarından elde edilmesi gereken geliri ifade

3 Hanefi Bostan, XV-XVI. Asırlarda Trabzon Sancağında Sosyal ve İktisadî Hayat, Ankara 2002, s. 397.

4 Zehra Topal, "Hatuniye İmareti Evkafina (Gülbahar Hatun Vakfina) Tahsis Edilen Gelirler", Akçaabat Yazıları II, Trabzon 2004, s. 82-92.

5 M. Tayyip Gökbilgin, "XVI. Yüzyıl Başlarında Trabzon Livası ve Karadeniz Bölgesi", Belleten, S: 26, s. 238.

$6 \quad$ TK. KKA, TD, nr. 43, s. 207-208; Bostan, a.g.e., s. 397. 
etmektedir. Bir önceki yıla ait muhasebe kaydı olmamakla birlikte o yıldan toplanamayan 126.625 akçelik gelirin bir sonraki yıla borç olarak intikal ettirildiği anlaşılmaktadır. Bu sebeple her yıl vakfın sahip olması gereken geliri ile güncel geliri arasında bir farklılık ortaya çıkmaktadır. Dolayısıyla 1615 'teki vakfın güncel geliri 635.585 akçedir. Muhasebe kayıtlarında, gelirlerin çeşitleriyle ilgili başlıklar oluşturulduğu ve şehir gelirleriyle tarımsal alanlardan gelen gelirlerin ayrı başlıklar altında olduğu ifade edilmektedir. Tarım alanlarından gelen gelirlerin vakfa ait cibâyetler olduğu, buna karşın şehir gelirlerinin ise vakfa ait hamam, boyahane, dükkân, ev, değirmen, arazi, bağ ve bahçe gelirleri olduğu görülmektedir. 538.500 akçe gelirin kırsal bölgelerden, 71.919 akçenin ise şehir gelirlerinden oluştuğu belirtilmektedir. Giderler olarak vakfın 175 personeline 188.520 akçe, mutfak harcamalarının 430.320 akçe, tamir ve diğer harcamaların ise 31.790 akçe olduğu ifade edilmektedir.?

1616 yılında vakfın gelir ve giderlerinde çok önemli bir değişiklik olmadığ 1 ifade edilmektedir. Bu yıla ait harcama kaleminde bir önceki yıla göre önemli bir farklılık olduğu göze çarpmakta; mutfak harcamalarının önemli oranda azaldığı, diğer harcamaların ise arttığı görülmektedir. Mutfak harcamalarından kesinti yapılarak 192.373 akçeye İstanbul'dan bazı inşat malzemelerinin satın alındığı belirtilmektedir. Vakfın çeşitli müesseseleri için büyük bir tamirat hazırlığında olduğu anlaşılmaktadır. Giderler arasında 24.000 akçelik kısmının da Haremeyn-i Şerif Vakfı olması sebebiyle Darüssade Ağası'na gönderildiği ifade edilmektedir. 1618 'de vakfın gelirlerinde daha önceki döneme oranla şehir gelirlerindeki çok küçük bir azalmanın dışında bir değişikliğin olmadığı belirtilmektedir. Toplam harcamanın 452.828 akçe ve bunun 220.792 akçesinin mutfak harcamaları olduğu görülmektedir. Bu y1l önceki dönemde mütevellinin aldığı buğday ve pirinç borcu olarak ise 55.629 akçenin ödendiği ayrı bir kalemde zikredilmektedir. ${ }^{8}$

Vakfın 1619'daki muhasebe kayıtlarının, yılın son dört ayına ait olduğu belirtilmektedir. Dolayssiyla bu yıla ait tüm gelir ve giderler tespit edilememektedir. 1622 y1lında vakfın güncel gelirinin 531.722 akçe olduğu ifade edilmektedir. Bunun 479.833 akçesinin tarımsal bölgelerden, kalanının ise vakfa ait diğer birimlerden geldiği belirtilmektedir. Harcamalar kısmında 24.000 akçenin Darüssade hazinesine gönderildiği ifade edilmektedir. 1629 yılına kadar muhasebe kayıtlarının mevcut olmadığı belirtilmektedir. 1629 y1lında vakfin güncel gelirinin 388.758 akçe olduğu, bunun önemli bir kısmını 346.000 akçeyle kırsal kesimden gelen gelirlerin oluşturduğu ifade edilmektedir. Diğer gelirler arasında hamamlardan yaklaşı 18.000 akçe, boyahaneden 10.000 akçe geldiği anlaşılmaktadır. Bu yıla ait harcama kalemleri arasında

Orbay, a.g.m., s. 443.

Orbay, a.g.m., s. 444. 
çarpıcı bilgiler de yer almaktadır. Kayıtlarda mutfak harcamaları görülmemektedir. Bunun temel sebebinin, 1625'te Trabzon'a yapılan Rus (Kazak) sald1rıları sırasında imâret mutfağının yandığı için kapanmasından kaynaklandığı anlaşılmaktadır. Harcama kalemleri içerisinde vakıf personeline 114.960 akçe yemek ücreti ödendiği ifade edilmektedir. Bu yıl Darüssaade hazinesine gönderilen akçenin 30.000 olduğu belirtilmektedir.

1634 'te vakfin 341.339 akçe güncel gelire sahip olduğu görülmektedir. Maaşlar için 227.955 akçe ödendiği ve mutfak harcamalarının olmadığı belirtilmektedir. Vakıf çalışanlarına yemek ücretinin verilmeye devam edildiği ifade edilmektedir. 1635 ve 1636 yıllarında vakıf gelir ve giderlerinde önemli bir değişikliğin olmadığı bu yıllarda imâret mutfağının kapalı olduğu anlaşılmaktadır. Mutfak harcamaları kısmında, vakıf çalışanlarına yemek ücreti ödendiği belirtilmektedir. 1642 yılında vakfın güncel gelirlerinin 396.828 akçe olduğu görülmektedir. Bu tarihte vakıf çalışanlarına verilen yemek ücretinden başka 18.670 akçelik bir mutfak harcamasının da olduğu görülmektedir. İmâret mutfağının yavaş yavaş faaliyete geçtiği anlaşılmaktadır. 1643 tarihinde vakfın 388.895 akçelik güncel gelirinin olduğu ve çalışanlarına yemek ücreti ödenmediği belirtilmektedir. İmâret mutfağının faaliyete geçtiği, mutfağa yapılan 132.340 akçelik gıda masrafindan anlaşılmaktadır. Bu yıl, daha önceki yılların aksine ilk kez vakıf bütçesinin 26.019 akçe açık verdiği ifade edilmektedir. 1644 tarihinde bir önceki yıla oranla vakfin gelirlerinde bir artış olduğu görülmektedir. Vakfin tüm gelirlerinin 570.846 akçe, güncel gelirinin ise 415.157 akçe olduğu ifade edilmektedir. Bu y1l maaşlar için 187.120 akçe, mutfak için ise 141.626 akçe harcama yapıldığı belirtilmektedir. Darüssaade Hazinesi'ne de 48.000 akçenin gönderildiği görülmektedir. Bunun iki yıllık ücret olduğu anlaşılmaktadır. Bütçe açığının 8.733 akçe olduğu belirtilmektedir. 1646 yılında güncel gelir 432.798 akçedir. Daha önceki yıllardan devreden ve toplanamayan gelirlerin miktarı ise 179.074 akçedir. Vakfın bu yıl da 5.230 akçe bütçe açığ 1 verdiği anlaşılmaktadır. 1644 'ten beri bütçe açığı var olmakla birlikte gittikçe azaldığı görülmektedir. ${ }^{10} \mathrm{Bu}$ muhasebe kayıtları dikkate alındığında vakfın gelirlerinde 1615'ten 1646'ya kadar git-tikçe azalma olduğu anlaşılmaktadır.

Hatuniye Vakfi'nın gelirleriyle ilgili verilen bu bilgilerden başka arşiv kaynaklarında muhtelif tarihlere ait vakfın gelirleriyle ilişkilendirilebilecek çeşitli kayıtlar mevcuttur. Bunları dikkate alarak vakfın gelir kalemleriyle ilgili başlıklar oluşturulmuştur. Tarımsal gelirleri oluşturan cibâyetler, hamam gelirleri, arazi, bahçe, zemin mukataaları, boyahane ve değirmen gelirleri vakfın en önemli gelirlerini teşkil etmektedir.

\footnotetext{
9 Orbay, a.g.m., s. 445-446.

10 Orbay, a.g.m., s. 446-449.
} 


\section{1-Vakfa Bağlı Cibâyetler}

Büyük vakıfların ayrı görevliler tarafindan idare edilen kısımlarına Cibâyet, vakıflara bağlı olan bu cibâyetlerin vergi gelirlerini tahsil eden görevlilerine de Câbi ya da Câbi-i Vakf denir. ${ }^{11}$ Cibâyetler, Hatuniye Vakfı'nın en önemli gelirlerini oluşturmaktadır.

Tahrir defterlerinde 16. yüzyılda İmâret-i Hatuniye Vakfına bağlı köyler ve buralardan tahsil edilen gelirler şu şekilde verilmiştir: Akçaabat nahiyesine bağl1 21 köyde 1655 hânede (80 Müslüman 1575 Hristiyan) 1830 nefer ve 150.997 akçelik gelir mevcuttur. Yomra'da sadece Hoç köyünde 48 hane ve 18 baştineden mürekkeb bir gelir, Maçka nahiyesinde beş köyde 542 hane (40 Müslüman, 502 Hristiyan), 634 nefer ile 56.507 akçelik gelir, İmâret-i Hatuniye Vakfi'na aittir. ${ }^{12}$

Hatuniye Vakfi'na bağlı köy, mahalle, mezra, yaylak gelirleriyle ilgili 1844 tarihli Trabzon Evkaf-1 Vakfiyesi Defteri'nde aşağıdaki bilgiler mevcuttur:

Tablo 2: Gelirleri Imâret-i Hatuniye Vakfina ait, Vakf-ı Kebir Kazası Köyleri

\begin{tabular}{|l|c|c|}
\hline Köy veya Mahalle İsmi & Statüsü & Gelir \\
\hline Akhisar & Köy & 480 \\
\hline Vacanoz & Köy & 475 \\
\hline Kızlağaç & Köy & 432,5 \\
\hline Şahmelik & Köy & 300 \\
\hline Saveriksa & Köy & 300 \\
\hline Akkise & Köy & 280 \\
\hline Oğuz & Köy & 267,5 \\
\hline Vuros & Köy & 252,5 \\
\hline Sarli & Köy & 250 \\
\hline Kefli & Köy & 250 \\
\hline Komantara & Köy & 250 \\
\hline Edra & Köy & 250 \\
\hline Yavabolu & Köy & 220 \\
\hline İbsalda & Köy & 212,5 \\
\hline Marina & Köy & 207 \\
\hline İskefiye & Köy & 200 \\
\hline Bendar & Köy & 187,5 \\
\hline Keramiya & Köy & 187,5 \\
\hline Makrinamoz & Köy & 185 \\
\hline Bedromida & Köy & 180 \\
\hline Yoroz & Köy & 177 \\
\hline Vardaliyoz & Köy & 175 \\
\hline
\end{tabular}

11 Ali Himmet Berki, Vakfa Dair Yazılan Eserlerle Vakfiye ve Benzeri Vesikalarda Geçen Istılah ve Tabirler, Ankara 1965, s. 9.

12 Gökbilgin, a.g.m., s. 240 


\begin{tabular}{|l|c|c|}
\hline İspavli & Köy & 175 \\
\hline Bodamlı & Köy & 175 \\
\hline Haldandoz & Köy & 175 \\
\hline Keraşon & Köy & 170 \\
\hline Sebekyüz & Köy & 165 \\
\hline Salava & Köy & 162,5 \\
\hline Kızlüzüm & Köy & 158,5 \\
\hline Kamuha & Köy & 155 \\
\hline Aşağa Makranyamuz & Köy & 155 \\
\hline Hublu & Köy & 150 \\
\hline Korkudan & Köy & 150 \\
\hline Arvela & Köy & 150 \\
\hline Ruka & Köy & 145 \\
\hline Levoysa & Köy & 142,5 \\
\hline Ellezli ma'a Kamena ve Badide & Köy & 130 \\
\hline Ceble & Köy & 125 \\
\hline Balaban & Köy & 125 \\
\hline Cavdanyoz & Köy & 125 \\
\hline Lagot & Köy & 120,5 \\
\hline Caferli & Köy & 112,5 \\
\hline Mirânlı & Köy & 110 \\
\hline Feline & Köy & 105 \\
\hline Hodala & Köy & 103 \\
\hline Cera & Köy & 100 \\
\hline Celâbi ma'a Furca & Köy & 96,5 \\
\hline Terlâta, altmıș dört tarafi & Köy & 90 \\
\hline Yalı & Köy & 87,5 \\
\hline Saveriksa'nın Zonida & Köy & 87,5 \\
\hline Mankaya & Köy & 78 \\
\hline Barharlı & Köy & 75 \\
\hline Adanoz, altmıș dört tarafi & Köy & 70,5 \\
\hline Hodala-i bayır & Köy & 70 \\
\hline Rozlik ma‘a Cayşiye & Köy & 70 \\
\hline Terlata, Bozuncı tarafi & Köy & 70 \\
\hline Mudura & Köy & 65,5 \\
\hline Kadahor Kızılağaç & Mahalle & 60 \\
\hline Mankanya & Köy & 60 \\
\hline Horeverha & Köy & 55,5 \\
\hline Hazer & Köy & 52,5 \\
\hline Azanos, Bozuncı tarafi & Köy & 50 \\
\hline Aliboz & Köy & 41 \\
\hline İsdil & Köy & 37,5 \\
\hline Hodala & & \\
\hline & & \\
\hline
\end{tabular}




\begin{tabular}{|l|c|c|}
\hline Komandara, altmıș dört tarafi & Mahalle & 37,5 \\
\hline Aksaklı & Köy & 33,5 \\
\hline Kamune Aydınlı & Mahalle & 20,5 \\
\hline Kıran & Mahalle & 5,5 \\
\hline TOPLAM & & 10.568 \\
\hline
\end{tabular}

Kaynak: VGM.d., nr. 651, s. 145-146.

Tablo 3: Gelirleri Imâret-i Hatuniye Vakfi'na ait Akçaabat Kazası Köyleri

\begin{tabular}{|l|c|c|}
\hline Köy veya Mahalle İsmi & Statüsü & Gelir (Kuruş) \\
\hline Metinkaniyâ & Köy & 539,5 \\
\hline Cayera ve Maklence & Köy & 404 \\
\hline Polathane Mahallatı & Mahalleler & 336,5 \\
\hline Cayerâ & Köy & 292,5 \\
\hline Gozoysa & Köy & 264,5 \\
\hline Mimera & Köy & 166 \\
\hline Ahanda & Köy & 151 \\
\hline Muhula & Köy & 126,5 \\
\hline TOPLAM & & 2.282 \\
\hline
\end{tabular}

Kaynak: VGM.d., $n r .651$, s. 147.

Tablo 4: Gelirleri Imâret-i Hatuniye Vakfi'na ait Akçakale Canibi Köyleri

\begin{tabular}{|l|l|l|}
\hline Köy veya Mahalle İsmi & Statüsü & Gelir (Kuruş) \\
\hline Korebi & Köy & 295 \\
\hline Mersin & Köy & 255 \\
\hline Karciya & Köy & 245 \\
\hline Guzari & Köy & 183,5 \\
\hline Koftez & Köy & 165 \\
\hline Şula & Köy & 137,5 \\
\hline Sari & Köy & 135 \\
\hline Vartara & Köy & 125 \\
\hline Cavana & Köy & 102,5 \\
\hline Lalank & Köy & 100 \\
\hline Cahori & Köy & 97,5 \\
\hline Zerâ & Köy & 95 \\
\hline İspendam & Köy & 85 \\
\hline Gutoz & Köy & 25 \\
\hline TOPLAM & & 2046 \\
\hline
\end{tabular}

Kaynak: VGM.d., nr. 651, s. 147. 
Tablo 5: Gelirleri Imâret-i Hatuniye Vakfi'na ait Samaruksa Canibi Köyleri

\begin{tabular}{|l|l|l|}
\hline Köy veya Mahalle İsmi & Statüsü & Gelir (Kuruş) \\
\hline Guzari & Köy & 457 \\
\hline Livera & Köy & 442 \\
\hline Samaruksa-i Kebir & Köy & 347 \\
\hline Samaruksa-i Sagir & Köy & 238,5 \\
\hline Hoç Kirasya & Köy & 184,5 \\
\hline Kurobi-i Kalemen & Köy & 152 \\
\hline Zafanos & Köy & 77,5 \\
\hline Hoç Palavrak & Köy & 68,5 \\
\hline Anbela & Köy & 36 \\
\hline Kosbitiyos, der ittısal-1 Livera & Mahalle & 22,5 \\
\hline Kapuköy, der ittısal-1 Livera & Mahalle & 10 \\
\hline İskobiya, der ittısal-1 Livera & Mahalle & 5 \\
\hline TOPLAM & & 2043 \\
\hline
\end{tabular}

Kaynak: VGM.d., nr. 651, s. 148.

Tablo 6: Vakfa Bağll Diğer Birimlerin Gelirleri

\begin{tabular}{|l|c|c|}
\hline İsmi & Statüsü & Gelir (Kuruş) \\
\hline Terme ve Fatsa & Kaza & 1500 \\
\hline Pazarsuyu ve Perşembe & Kaza & 500 \\
\hline Yaylaklar (Maçka'da) & Mezra, Yaylak & 152 \\
\hline İcareler & & 556 \\
\hline Diğer gelirler & & 1359 \\
\hline TOPLAM & & 4067 \\
\hline
\end{tabular}

Kaynak: VGM.d., nr. 651, s. 148.

Tablo 7: Vakfa Bağgl İdari Birimlerin Toplam Gelirleri

\begin{tabular}{|l|c|c|}
\hline İdari Birimler & Gelir (Kuruş) & \%'lik Oranı \\
\hline Vakf-1 Kebir & 10568 & $\% 50,30$ \\
\hline Akçaabat & 2282 & $\% 10,86$ \\
\hline Akçakale & 2046 & $\% 9,74$ \\
\hline Samaruksa & 2043 & $\% 9,72$ \\
\hline Diğer Gelirler & 4067 & $\% 19,36$ \\
\hline TOPLAM & 21006 & $\% 100,00$ \\
\hline
\end{tabular}

Kaynak: VGM.d., nr. 651, s. 149. 
Gelirleri İmâret-i Hatuniye Vakfi'na ait cibâyetlerle ilgili muhtelif tarihlere ait çeşitli kayıtlar mevcuttur. Bu kayıtlarda bazı tarihlere ait cibâyetlerin yıllık gelirleri mevcuttur.

\section{1-Gümüş-i kadîm Cibâyeti}

Vakfa ait cibâyetlerden birisi Amasya'ya bağlı Gümüş-i kadîm cibâyetidir. Cibâyetle ilgili H. 969 (M. 1562) tarihli bir kayıt mevcuttur. Kayıtta Ömer Bey'in, 968 Rebiülevvelinin 13. gününden 3 y1l sonuna kadar 86.000 akçeye, Gümüş-i kadîm cibâyeti mukataasına günlük 5 akçe ücretle câbi olduğu ifade edilmiştir. Aynı kazadan Sefer b. Esseyyid İbrahim adlı sipahi, 6.000 akçe fazlasıyla ve mal zararına kefil göstererek iltizamın kendisine verilmesini talep etmiştir. Vakıf mütevellisinin Sefer adlı sipahi hakkında bir araştırma yaptırması neticesinde, Sefer'in zalim birisi olduğu, şer'e ve kanuna aykırı olarak vakıf köylüsüne zulmettiği ifade edilmiştir. Ayrıca Gümüş kadısı tarafından da Sefer'le ilgili benzer bilgiler verilince, mütevellinin Gümüş-i kadîm'e gittiği, ehl-i vukuftan ve reayadan Sefer'le ilgili olumlu bir bilgi alamayınca Sefer'in teklifini kabul etmediği ifade edilmiştir. ${ }^{13} \mathrm{Bu}$ kayıt, gerçekten de çok çarpıcı bilgiler ihtiva etmektedir. Vakıf mütevellilerinin, vakfa bağlı cibâyetlerin hem iltizama verilmesi hem de daha fazla ücretle talip olunması durumunda ilgililer hakkında ciddi bir araştırma yaptıkları anlaşılmaktadır. Özellikle reayanın korunmaya çalışılarak cibâyetin, vakfin gelirlerini sekteye uğratacak kişilere verilmediği görülmektedir.

\section{2-Pazarsuyu Cibâyeti}

Cibâyet, Giresun iline bağlı Bulancak kazasındadır. Bu cibâyetle ilgili bir kayda rastlanmıştır. H. Şaban 962 (M. Nisan 1562) tarihli sicil kaydına göre Liyu veledi Keraki, Hatuniye Vakfı'ndan olan Pazarsuyu cibâyeti câbisi Cafer b. Abdullah'ı dava etmiştir. Liyu, İstanbul'dan gemiyle gelirken Câbi Cafer'in kendisine ait olan 2 çukasını ve 3 zira Samardin çukasını alarak kendisine zarar verdiğini ifade etmiştir. Cafer ise Liyu'nun gemisini Vona Limanı'na getirip mallarını boşalttıktan sonra başka bir gemiye koyduğunu ve bu nedenle yarım gümrük ödemesi gerektiği cevabını vererek o da Liyu'dan davacı olduğunu belirtmiştir. Liyu, Vona Limanı'nın asıl iskele olmadığını, bu nedenle yarım gümrüğün de kanuni olmadığını ifade ederek şimdiye kadar böyle bir uygulamanın yapılmamış olduğunu söylemiştir. Cafer'den iddiası için delil talep edilmesi üzerine Ali Reis b. Ramazan ve Hızır b. İshak Vona Limanı'na gelmişler ve malı bir gemiden başka bir gemiye aktarıp gidenden yarım gümrük vergisi; gemiden dışarı çıkarıp köyde satışa sunandan da eskiden beri yarım gümrük vergisi alındığını ifade etmişlerdir. Bu durumun

13 T.Ş.S. 1817, 69/4. 
eskiden beri adet ve kanun olduğu belirtilmiştir. ${ }^{14}$ Cibâyetle ilgili yeterli kayı1t olmadığ 1 için vakfa ne kadar gelir getirdiğine dair bilgi mevcut değildir.

\title{
1.3-Bayramlu Cibâyeti
}

Cibâyet, Ordu iline bağlı Çarşamba kazasındadır. Cibâyetle ilgili olarak H. 23 Ramazan 973 (M. 13 Nisan 1566) tarihli bir kayda göre, Câbi Ramazan Ağa b. Süleyman mahkemede, cibâyete bağlı Boztepe vakıf köyünden Seydi b. Mustafa ve kardeşi Süleyman'in kendi tahvillerinden olan mahsullerinin tamamını aldığını beyan etmiştir. ${ }^{15}$

Başbakanlık Osmanlı Arşivi Maliyeden Müdevver Defterlerde Bayramlu cibâyetiyle ilgili H. 26 Cemaziyelevvel 1000 (M. 10 Mart 1592) tarihli bir kayda rastlanmıştır. Bu kayıtta Bayramlu cibâyeti gelirleri gösterilmektedir. Cibâyete bağlı Akyazı, Bucak, Pazarsuyu ve Güre Deresi yerlerinin çeltik mahsulatı ve diğer köylerle birlikte Alahnas, Saçlu köylerinin çift resmi, caba, bennak, mal-1 makud, abd-i itk, yave, kaçgun, beytü'l-mal, tapu-yı zemin vergileri, iskele gümrügüü, Ordu ihtisap pazarı, Bulancak ve Pazar-1 cedid mukataalarının, Kara Şaban ve Mustafa'nın uhdesinde olduğu belirtilmiştir. ${ }^{16}$

\section{4-Akçaabat Cibâyeti}

Vakfa gelir getiren önemli cibâyetlerden birisi Akçaabat cibâyetidir. Trabzon Şeriye Sicilleri'nde Akçaabat cibâyetine ait H. 12 Şaban 972 (M. 15 Mart 1565) tarihli kayda göre Akçaabat câbisi İsmail Ağa b. Murad mahkemede Cafer Ağa'yı dava etmiştir. Cafer Ağa'nın İstanbul'a giderek emr-i şerifle kendi cibâyeti de dâhil olmak üzere cibâyetleri dört cibâyette biriktirdiğini ve mukataanın 1.000 flori artırıldığını ifade etmiştir. Cafer Ağa, dört cibâyeti resmiyette birleştirdiğini ancak İsmail Ağa'nın cibâyetinin eskiden olduğu gibi onun üzerinde kaldığını ve kendisinden herhangi bir alacak talep etmediğini, eğer bu söylediklerine aykırı bir hareketi olursa mahkemenin kabul etmemesini talep etmiştir. İsmail Ağa'nın bu durumu tasdik ettiği belirtilmiştir. ${ }^{17}$

Maliyeden Müdevver Defterlerde H. 26 Cemaziyelevvel 1000 (M. 10 Mart 1592) tarihli belgede Akçaabat cibâyeti gelirleri yer almaktadır. Cibâyete bağl1 Yavebolu, Hodala, Kirasun, Karziya, Marine, Kordil, Yoros ve Mersin mukataaları, ispenç, rüsum-1 örfiyye, beytü'l-mal, abd-i 1tk, yave, kaçgun, rüsum-1 tapu-yı zemin, keten gümrügü, iskele, mahi (balık) vergilerinin Kerasi'nin uhdesinde olduğu belirtilmiştir. ${ }^{18}$

H. 1053 Recep evailine (M. Eylül 1643) ait bir kayıtta Hatuniye

\author{
T.Ş.S. 1817, 110/3. \\ T.S.S.S. $1819,64 / 5$. \\ $B O A$, MAD, nr. 15996, s. 4. \\ T.S.S. $1818,59 / 1$. \\ $B O A$, MAD, nr. 15996, s. 5.
}


Vakfi'na ait Akçaabat cibâyetinde, önceden câbi olan Kara Naib denilen Muslihiddin Halife, Kılida köy halkını Kethüda Resul, Hasan ve Süleyman huzurunda mahkemede dava ederek, reayanın ziraat yaptığ yerlerin vakıf toprağı olduğunu, bu yerleri kesimle işlediklerini ve senede 150 kuruş ürünü vakfa verirlerken câbisi olduğunda reayanın 79 kuruş verdiğini ifade etmiş ve kalanını talep etmiştir. Köy halkı eskiden aşar-1 şeriyyeleri karşılığında vakfa 5000 akçe verdiklerini, buna karş1lık da 100 kuruşu câbiye verdiklerini belirtmişlerdir. Bunun üzerine Kethüda Resul, Hasan ve Süleyman'a vakfa ait mahsulün 100 kuruştan fazla olup olmadığına yemin teklif edildiğinde onlar da yemin edip vakfa zulm etmediklerini ifade etmişlerdir. Bu durumda câbi Muslihiddin Halife'ye yemin teklif edilmiş, Muslihiddin Halife de reayadan 79 kuruştan fazla almadığına yemin edince kalan 21 kuruşun köy halkından alınmasına karar verilmiştir. ${ }^{19}$

Akçaabat cibâyetiyle ilgili bir başka kayıt da cibâyete bağlı bazı köylerdeki vergilerin toplanmasıyla ilgilidir. H. 1054 Muharrem evaili (M. Mart 1644) tarihli kayda göre Akçaabat câbisi olan Osman Beşe b. Kurd mahkemede Hacı Mehmet Ağa'yı dava ederek Akçaabat'ta câbisi olduğu Vacanos ve Erniyan köylerinin vergilerinin toplanması işini Hacı Mehmed'e sipariş ederek kendi yerine vekil tayin ettiğini ve 3 seneden 1 senenin öşür ve vergilerini ondan aldığını, geri kalan 2 senenin vergilerinin ise Hacı Mehmet'te kaldığını belirterek bunu talep etmiştir. Mehmet Ağa, köylerin öşür ve vergilerini Osman Beşe'ye verdiğini ve aralarında tartışma yaşandığını, aracılar vasıtasıyla 100 adet riyalî kuruşa sulh olunduklarını, elinde önceki Trabzon Kadısı Mevlana Mustafa Efendi'nin verdiği hüccet olduğunu belirtmiştir. Osman Beşe hüccete rağmen aldığını inkâr edince Osman Çelebi b. Yahya Beşe ve Hacı Ahmet Beşe b. Mustafa köylerin öşür ve vergilerinin toplandığını, Osman Beşe ile Mehmet Ağa arasında tartışmalar olduğunu, aracılar vasıtasıyla Mehmet Ağa'nın 100 kuruşu Osman Beşe'ye verip sulh yaptıklarına şahitlik ettiler. Bunun üzerine Osman Beşe şikâyetinden men edilmiştir. ${ }^{20}$

Akçaabat cibâyetiyle ilgili bir diğer kayıt ise câbi tayini ile ilgilidir. Merkezden gönderilen H. 1054 Muharrem (M. Mart 1644) tarihli kayda göre Hatuniye Vakfı cibâyetlerinden Akçaabat cibâyeti mukataası, önceden 120 bin akçeyken 1054 Muharremi başlangıcı dâhil olmak üzere senesi 120 bin akçeye Mehmet Ağa'nın kefaletiyle Hacı Ahmet'e iltizam edilmiştir. Hacı Ahmet'ten 400 adet kuruş kira ve 32.000 akçe peşin alınıp kalan 88.000 akçenin aydan aya ödenmesi şartı konulmuştur. Bu durumun vakfa ve reayaya faydalı olması temennisiyle iltizam hissesine ortak olarak Hacı Ahmed'e vesika verildiği belirtilmiştir. ${ }^{21}$ 
H. Rebiyülevvel 1060 (M. Mart 1650) tarihli bir kayıt da Akçaabat cibâyeti mukataasının verilişi ile ilgilidir. Kayda göre cibâyetin 1650 Mart ayından itibaren sene sonuna kadar 120.000 akçeye Mustafa'ya verilmiş ve şart olarak da iltizamın aydan aya vakfa teslim edilmesi hususu belirlenmiştir. Mal zararına Sadi Çelebi ve İmam Şaban Efendi'nin kefil olduğu belirtildikten sonra kendisine vesika verildiği ifade edilmiştir. ${ }^{22}$

Cibâyetin vakfa getirdiği gelir konusunda kesin bir bilgi verememekle birlikte bu kayıtlar, en azından 1640'lı yıllarda cibâyetin yıllık 140.000 akçe gelire sahip olduğunu ortaya koymaktadır. 1650'lerde ise cibâyetin gelirlerinde azalma olduğu ve yıllık 120.000 akçeye düştüğü anlaşılmaktadır.

\section{5-Pulathane Cibâyeti}

Vakfin cibâyetlerinden birisi de Akçaabat'a bağlı Pulathane cibâyetidir. Cibâyetle ilgili H. 9 Rebiyülahir 969 (M. 17 Aralık 1561) tarihli bir kayda göre Atina kazasından Mustafa b. Ali, mahkemede, Pulathane köyünden Rüstem b. Yusuf'un gemisinde Varna'dan gelirken yolda vefat ettiğini, gemide olan muhallefatını Pulathane köyü câbisi İbrahim'in beytü'l-mal diyerek vakıf için aldığını ifade etmiştir. Rüstem b. Yusuf'un muhallefatının Atina kazasında olan zevcesi Hüsniye bt. İskender, Ayşe ve Fatıma adlı kız kardeşleri, Kamer ve Şahin adlı erkek kardeşlerine intikal ettiğini belirterek talebini dile getirmiştir. Atina kadı naibi Mevlana Mehmed b. Mustafa, Mustafa b. Yusuf ve Süleyman b. İskender'in de bu yönde şahitlik etmeleriyle muhallefatın Rüstem b. Yusuf'un varislerine verilmesi gerektiği belirtilmiştir. ${ }^{23}$

H. 10 Receb 1037 (M. 16 Mart 1628) tarihli bir başka kayıt Pulathane cibâyetine câbi tayini ile ilgilidir. Kayıtta Hatuniye Vakfi'na bağlı Pulathane mukataasının daha önce 1036 Cemaziyelevveli'nin 22'sinden sene sonuna kadar 38.000 akçeye Zülfikar câbi tasarrufunda olduğu ve bu senenin mahsulünün vakfa teslim edildiği belirtilerek 1037 Receb'inden sonra cibâyetin yeni talibi olmadığı ve reayanın memnun olması hasebiyle Zülfikar câbi üzerinde kalması uygun görülmüştür. Zülfikar Câbi'nin günlük 5 akçe cibâyet ücreti alarak cibâyet gelirini eksiksiz bir şekilde aydan aya vakfa vermesi şartıyla kendisine vesika verildiği ifade edilmiştir. ${ }^{24}$

H.1 Ramazan 1041 (M. 22 Mart 1632) tarihli bir başka kayıt da Pulathane cibâyeti mukataasının Zülfikâr Câbi'ye verilmesiyle ilgilidir. H. 1038 senesi Pulathane cibâyetinin Zülfikar Câbi uhdesinde olduğu ve 38.000 akçeyi deftere kaydedip vakfa verdiği belirtildikten sonra 1039 senesi Recebi'nin 26. günü olan Mart başlangıcından itibaren Zülfikar Câbi'ye rakip ve başka talip olmayınca 38.000 akçeye yine kendisine verildiği ifade edilmiştir. 5 akçe 
günlük ücreti ve cibâyetin gelirinin aydan aya vakfa verilmesi ve yetecek miktarda mal kefalet göstermesi şartıyla kendisine kimsenin müdahale etmemesi istenmiştir. ${ }^{25}$

H. 8 Rebiyülevvel 1059 (M. 22 Mart 1649) tarihli bir kayıt da vakfa bağlı mukataalardan Pulathane cibâyetine câbi tayini ile ilgilidir. Kayda göre Pulathane cibâyetinin 1059 Safer'inin 27. günü (M. 12 Mart 1649) başlang1cindan sene sonuna kadar 42 bin cedid akçe hesabı üzere Derviş Beşe b. Ali Çelebi'ye verildiği ifade edilmiştir. Derviş Beşe'nin 42.000 akçeyi aydan aya vakfa teslim etmesi şartıyla iltizamın verildiği ifade edilmiştir. ${ }^{26}$

H. 25 Şevval 1059 (M. 1 Kasım 1649) tarihli bir diğer kayda göre Trabzon İskelesi ve çevresi mukataasına emin olan Mehmed Ağa, Hatuniye Vakfi'ndan Pulathane câbisi Davud huzurunda mahkemede, Çatani köyünden Simyon oğlu tacir Benayut'un şimdiye kadar getirdiği malların gümrüğünü iskele eminlerinin aldığını ifade ederek câbi Davud'un, tacir Benayut'un getirdiği çadır ve diğer malların gümrügünün vakfa ait olduğunu söyleyerek kendisine müdahale ettiğini ve bu durumun araştırılmasını talep etmiştir. Kendisine sorulduğunda Câbi Davud, şimdiye kadar Benayut'un getirdiği malların gümrügünü vakıf adına câbilerin aldığını, iskele eminlerinin almadığını söylemiştir. İskele emininden bu konuyla ilgili delil istenince Mehmed Ağa b. Hüseyin Çavuş, Mustafa Ağa b. Ömer Çavuş ve Veli Çelebi b. Hızır Bey, iskele emini Mehmed Ağa'nın iddiasının doğru olduğuna şahitlik etmişlerdir. Bunun üzerine mahkeme, gümrüğü, eskiden olduğu gibi emin olanların almasına karar vermiş ve câbiye bu hususta tembih edildiği belirtilmiştir. ${ }^{27}$ Eldeki kayıtlardan cibâyetin 1628 ve 1632 yıllarında 38.000, 1649 yılında ise 42.000 akçe vakfa gelir getirdiği anlaşılmaktadır. Bu durumda cibâyetin gelirlerinde bir artış olduğu görülmektedir.

\title{
1.6-Hoşoğlan Cibâyeti
}

XVI. yüzyılın sonlarına ait Maliyeden Müdevver Defterlerin birinde $\mathrm{H}$. 26 Cemaziyelevvel 1000 (M. 10 Mart 1592) tarihli belgede, Hoşoğlan cibâyeti gelirleri yer almaktadır. Cibâyete bağlı Hoşoğlan, Mesariya Müslim Bey, Mesariya Ali Çelebi, Ulasi, Mamad, Holomana, Cayera, Sera, Asor köyleri, ispenç, rüsum-1 örfiyye, beytü'l-mal, abd-i ttk, yave, kaçgun, rüsum-1 tapu-y1 zemin, keten gümrüğü gelirlerinin Osman'ın uhdesinde olduğu ifadeleri bulunmaktadır. ${ }^{28}$

Hoşoğlan cibâyetiyle ilgili H. Rebiyülevvel 972 (M. Ekim 1564) tarihli başka bir kayıtta Hoşoğlan câbisi Ahmed b. Abdullah, Mesariya Ali Çelebi vakıf köyünden olup ölen Poroti veledi Beraşküve'nin zevcesi Elena bt.

\author{
T.S.S. $1827,98 / 5$. \\ T.S.S. $1831,87 / 7$. \\ T.S.S. 1831, 28/11. \\ $B O A$, MAD, nr. 15996, s. 3.
}


Kastalyu'yu mahkemeye getirtip vakıf köyünde işlettikleri asmalı bağ mülkünün öşrünü eskiden beri verirken 3 yıldır vermediklerini söyleyerek dava etmiştir. Elena mahkemedeki beyanında, önceden öşrü vakfa verdiklerini 3 yıldır Zaim Ali Bey'in burasının kendi tımarı olduğunu söyleyerek öşrü aldığını ifade etmiştir. Câbi Ahmet'in gösterdiği yeni kanunnameye bakıldığında bazı yerlerde ihmal olduğu ve asmadan hasıl olan hububat vergisini dahi bir başka sipahinin aldığ görülmüştür. Bunun üzerine bahsedilen mülklerin öşrünün eskiden olduğu gibi vakıf için alınmasına mahkeme tarafindan karar verilmiştir. ${ }^{29}$

H. Safer 1053 (M. Nisan 1643) tarihli bir kayda göre Hoşoğlan câbisi Mehmed Çelebi mahkemede Yakup Ağa b. Cafer huzurunda cibâyete bağl1 Hoşoğlan değirmenleri yakınında yer alan 40 yıldan beri boş kaldığını ispat ettiği boz toprağı ve ceviz ağacının işletim hakkını Yakup Ağa'ya bıraktığını, karşllı̆ğında 15 kuruş alarak işletmesi için temessük verdiğini ifade etmiştir. ${ }^{30}$

Hoşoğlan cibâyetiyle ilgili H. 1054 Muharrem (M. Mart 1644) tarihli bir kayıt da câbi tayini ile ilgilidir. Buna göre Hatuniye vakfı mukataalarından Hoşoğlan cibâyeti mukataasının bundan önce senesi 40.000 akçeye Mehmed Çelebi'deyken 1054 Muharreminin 2. gününde Mart başlangıcından itibaren senesi 40.000 akçeye Osman Beşe'ye verilmiştir. Müezzin Mustafa'nın kefaletiyle ve 40.000 akçeyi aydan aya vakfa ödemesi şartıyla kendisine vesika verildiği beyan edilmiştir. ${ }^{3}$

H. Zilhicce 1058 (M. Aralık 1649) tarihli bir kayıt da Hoşoğlan cibâyetine tayin edilen câbiyle ilgili bir kayda göre Hatuniye Vakfı'na ait Hoşoğlan cibâyetine Darüssaadet Ağası Evkaf Nazırı İbrahim Ağa'nın arzıyla ölen câbi Mehmet yerine oğlu Mustafa, 1058 Zilkade ayının son gününden sene sonuna kadar günlük 7 akçeyle câbi olarak tayin edildiği belirtilmiştir. Ücretini vakıf mahsulünden alması ve kendisine kimsenin mani olmaması için berat verildiği ifade edilmiştir. ${ }^{32}$

Hoşoğlan cibâyeti ile ilgili bir başka kayıt H. 28 Safer 1059 (M. 13 Mart 1649) tarihine aittir. Kayıtta Hatuniye mukataalarından olan Hoşoğlan cibâyetinin 1058 senesinde Mustafa tarafından işletildiği belirtilmiştir. 1059 senesi mukataasının da 1059 Saferinin 28. Mart başından sene sonuna kadar 38 bin akçeye Mustafa'ya verildiği, onun da aydan aya vakfa 3150 akçe vermek üzere iltizamı kabul ettiği ifade edilmiştir. Yeni câbinin gerekli kefili bulmasından sonra kendisine tezkere verildiği belirtilmiştir. ${ }^{33}$ Eldeki kayıtlara göre 1644 y1lında senelik 40.000 akçe olan cibâyet gelirinin azalarak 1649'da 38.000 akçeye düştüğü görülmektedir.
T.Ş.S. $1818,91 / 3$.
T.S.S.S. $1830,39 / 8$.
T.S.S. 1830, 91/5.
T.Ş.S. $1831,81 / 8$.
T.Ş.S. 1831, 82/5. 


\section{7-Samaruksa Cibâyeti}

Hatuniye Vakfi'na bağlı önemli cibâyetlerden biri de Samaruksa cibâyetidir. H. 5 Recep 969 (M. 11 Mart 1562) tarihli kayit Samaruksa-i Kebir köyünün mukataasıyla ilgilidir. Kayıtta Falkozlu Lefter b. Beraşkeva, köy halkından Hristodol b. Yuri'yi dava ederek önceden köyün mahsulünün bir kısmını 3 yıl mukataa ile aldığını, Hristodol'un babasının köyün kethüdası olduğu için köyden tahsil ettiği mahsûl akçesinden zimmetinde 1000 akçe alacağı kaldığını ve muhallefatından talep ettiğini beyan etmiştir. Hristodol mahkemede babasının sağlığında bütün makbuzlarını eksiksiz olarak Lefter'e verdiğini ve haklaştıklarını ifade etmiştir. Liyu b. Save ve Kaluri b. Vasıl'ın da Hristodol lehine mahkemede şahitlik etmeleri üzerine Hristodol'un beraatine karar verilmiştir. ${ }^{34}$

H. 4 Şaban 969 (M. 9 Nisan 1562) tarihine ait bir kayıt, cibâyete câbi tayini ile ilgilidir. Hatuniye vakfi mütevellisi mahkemede mutemed adamı İskenderle tezkere gönderip 968 Cemaziyelahirinin 14'ü (M. 2 Mart 1561) olan Mart başlangicında Samaruksa cibâyetini ona iltizam ettiğini belirtmiş̦tir. İskender'in evkaftan topladığı akçenin hesabı görüldügü̈nde defter gereğince zimmetinde 2.250 akçe olduğu, bunun 1.050 akçesi hizmeti mukabelesinde vazifesine hesap olunmuş, kalan 1.200 akçeye ise kefil olduğu beyan edilmiştir. ${ }^{35}$

Samaruksa cibâyeti ile ilgili H. Receb evaili 1029 (M. Haziran 1629) tarihli bir başka kayıtta Hatuniye mütevellisi İbrahim Ağa mahkemede 1028 senesine ait Samaruksa cibâyeti mahsulatının tamamını câbisi İsmail'den aldığını ve zimmetinde alacağı kalmadığını belirtmiştir. ${ }^{36}$ Ayrıca mütevelli İbrahim Ağa, İsmail Ağa zimmetinde beygir bahasından olan 3520 akçeyi vakıf için aldığını beyan etmiştir. ${ }^{37}$ Yine dava esnasında mütevelli İbrahim Ağa mahkemede Samaruksa câbisi İsmail Ağa huzurunda, cibâyetin 1059 senesi mahsulünden 6.700 akçe nakit aldığını ve borcu olduğunu ifade etmiştir. ${ }^{38}$ Tekrar görülen dava sırasında İsmail Ağa mahkemede mütevelli İbrahim Ağa huzurunda, İbrahim Ağa'nın aldığı 6.700 akçe borcu ödemesi halinde Samaruksa câbiliğinden feragat edeceğini beyan etmiştir. ${ }^{39}$

Cibâyetle ilgili H. Cemaziyelahir evaili 1030 (M. Nisan 1621) tarihli bir kayıtta Samaruksa câbisi Ali Câbi b. Mustafa'nın mahkemede Samaruksa'ya bağlı yerlerde 3 senelik tahvili 147.000 akçe olan iltizamın kendinde olduğunu, bir senelik hisse olan 57.000 akçeyi vakfa teslim etmiş olmakla birlikte zararda olduğunu, bazı başka köylerde de halkın zarar ettiğini ve cibâyeti bıraktığını belirtmiştir. Başkasının görevlendirilmesi istendiğinde herhangi bir

\footnotetext{
T.Ş.S. $1817,59 / 1$.

T.S.S. $1817,110 / 1$

T.Ş.S. 1821, 34/1.

Aynı defter, 34/2.

Aynı defter, 34/3.

Aynı defter, 34/4.
} 
talip olmayınca "ayan-1 vilayete" haber verilmiş olup Hacı İshak Beşe ve oğlu Mustafa'nın iltizamı kabul ettiği belirtilmiştir. 1030 Rebiyülahiri'nin 17. günü (M. 11 Mart 1621) olan Mart başlangıcından 3 sene sonuna kadar tahvili 126.000 akçeye verildiği ifade edilmiştir. Senelik akçeden peşin olarak 31.000 akçenin vakfa ödendiği beyan edilmiştir. Cibâyeti alan kişiler cibâyete bir başkasının talip olması halinde ödedikleri peşin ücretin kendilerine geri ödenmesi konusunda mütevelli İbrahim Ağa tarafindan imzalı ve mühürlü temessük talep etmişlerdir. Bunun üzerine mahkemeden bu konuda kendilerine hüccet verildiği belirtilmiştir. ${ }^{40}$

Cibâyetle ilgili bir başka kayıt H. Şaban evaili (M. Mart 1632) tarihine aittir. Kayda göre Hatuniye Vakfi'na bağlı Samaruksa cibâyetinin 1040 senesine ait mukataasının 42.000 akçe ve Ali uhdesinde olduğu ifade edilmiştir. Ali Câbi'nin bu akçeyi vakfa teslim ettiği ifade edilerek 1041 senesinin mukataasının da kendisine verildiği belirtilmiştir. Câbinin mal zararına karşı kefil göstermesiyle birlikte günlük 5 akçe vazife ücretini alması ve mukataa gelirini aydan aya vakfa teslim etmesi gerektiği beyan edilmiştir. ${ }^{41}$

H. Ramazan 1042 (M. Mart 1633) tarihli kayıtta Samaruksa cibâyetinin gelirleri ve nerelerden temin edildiği yer almaktadır. Samaruksa-i kebir ve sagir, Hoc-1 kebir ve sagir, rüsum-1 örfiye, beytü'l mal, mal-1 ayn, mal-1 nukud, abd-i atik, yave, kaçgun, resm-i tapu-yı zemin, gümrük-i ketan, gayr-i bervechi serbest, resm-i yaylak mescid-i Osman Bey, mültezim Ali câbi zimmetinde olduğu belirtilmiştir. ${ }^{42}$

Samaruksa cibâyeti ile ilgili başka bir kayıt câbi tayini ve cibâyet geliri ile ilgilidir. H. Ramazan evaili 1042 (M. Mart 1633) tarihli kayda göre Samaruksa cibâyetinin 1041 senesi mukataasının Ali Câbi üzerinde olduğu ve yıllık 42.000 akçelik geliri vakfa teslim ettiği ifade edilmiştir. 1042 yılı cibâyetinin Ramazan'ın birinci günü Mart başlangıcından sene sonuna kadar yine 42.000 akçeye (kuruş hesabı olarak 420 kuruş) Ali câbiye verildiği belirtilmiştir. Mahkemede Ali Câbi'nin bu işin üstesinden gelmeye kadir bulunduğu, reayaya ve vakfa faydalı olduğu ifade edildikten sonra kendisine vesika verildiği zikredilmiştir. ${ }^{43}$

Cibâyetle ilgili bir diğer kayıt H. Ramazan 1044 (M. Mart 1635) tarihine aittir. Kayda göre Samaruksa cibâyetinin mukataasının 1043 senesinin 42.000 akçeye Ali Çelebi uhdesinde olduğu, 1044 senesinin de sene sonuna kadar yine 42.000 akçeye Ali Çelebi'ye verildiği ifade edilmiştir. Mal zararına karşı kefil gösterildiği ve 42.000 akçenin aydan aya vakfa ödenmesi gerektiği belirtilmiştir. ${ }^{44}$ 
Merkezden gönderilen H. Muharrem 1053 (M. Mart 1643) tarihli bir hüküm de câbi tayini ile alâkalıdır. Kayıtta Samaruksa cibâyetine ait 1051 yılının mukataasının Mahmud Câbi'de olduğu, 1052 yılına ait cibâyet mukataasının ise Mart başından sene sonuna kadar 40.000 akçeye, geliri aydan aya vakfa vermesi şartıyla, Ali Câbi'ye verildiği ifade edilmiştir. ${ }^{45}$

H. Rebiyülevvel 1059 (M. Mart 1649) tarihli bir kayit da Samaruksa cibâyetine câbi tayini ile ilgilidir. Kayda göre cibâyetin mukataasının senesi daha önce 40.000 akçeye Mustafa' dayken 1059 senesi Mart başından sene sonuna kadar 40.000 akçeye Ali Çelebi uhdesine verildiği ifade edilmiştir. Mukataanın aydan aya vakfa verilmesi ve mal zararına Abdurrahman Ağa'nın kefil olmasıyla Ali Çelebi'ye vesika verildiği belirtilmiştir. ${ }^{46}$

Samaruksa cibâyetine câbi tayini ile ilgili bir başka kayıt da H. Rebiyülevvel 1060 (M. Mart 1650) tarihine aittir. Kayıtta cibâyetin mukataasının senesinin daha önce 40.000 akçeye Ali Câbi'de olduğu 1060 senesi Mart'indan itibaren ise iltizamı 40.000 akçeye Davud Çelebi'nin aldığı ifade edilmiştir. Mal zararına kifayet edecek kefil gösterdikten sonra Davud Çelebi'nin cibâyet gelirini aydan aya vakfa vermesi gerektiği belirtilmiştir. ${ }^{47}$

Samaruksa cibâyeti ile ilgili olan kayıtlar dikkate alındığında cibâyetin gelirlerinin 1621 tarihinde yıllık 57.000 akçe olduğu ancak câbinin zarar ettiği ve görevini bıraktığı anlaşılmaktadır. Bu nedenle cibâyete bu ücret üzerinden kimsenin talip olmadığı, cibâyet gelirlerinin de yıllık 42.000 akçeye düşürüldügü görülmektedir. Eldeki kayıtlara göre en azından 1635 tarihine kadar cibâyet gelirlerinin bu düzeyde sabit kaldığı düşünülmektedir. 1643 tarihinde ise cibâyet gelirlerinin yıllık 40.000 akçe olduğu belirtilmektedir. Dolayısıyla 2.000 akçelik bir azalma tespit edilmiştir. 1650 tarihine kadar da cibâyet gelirlerinin sabit kaldığı anlaşılmaktadır.

Kayıtlardan cibâyete yapılan câbi tayinleri ile ilgili bir takım bilgilere ulaşmak mümkündür. Cibâyete yapılan câbi tayinlerinde dikkat çeken hususlardan biri Ali adlı câbinin uzun yıllar bu görevi sürdürmesidir. Kayıtlardan câbi Ali'nin 1621'den 1644'e kadar aralıklarla bu görevi sürdürdüğü anlaşımaktadır. Bir kayıtta Ali'nin reayaya ve vakfa faydalı olduğunun belirtilmesi câbilik vazifesini uzun süre sürdürmesinde etkili olduğu düşünülmektedir.

\section{8-Terme Cibâyeti}

Samsun iline bağlı Terme kazası da Hatuniye Vakfi'na ait cibâyetlerden birisidir. Cibâyet gelirleri Maliyeden Müdevver Defterlerde H. 26 Cemaziyelevvel 1000 (M. 10 Mart 1592) tarihli belgede şu şekilde sıralanmaktadır: Emir Hasanl1, Emirdoğan Akça, Şahabeddin ve Gürköy köyleriyle birlikte Fatsa'ya 
bağlı Kurfanyu ve Kocalu köylerinin, rüsum-1 çift, caba, bennak vergileri, beytü'l mal, abd-i 1tk, yave, kaçgun, rüsum-1 tapu-yı zemin, iskele gümrük vergisi, ihtisab-1 bazar, sabuncuhane ve çeltikhane vergileri. Bu cibâyet gelirlerinin Mahmud ve Ali uhdesinde olduğu ifade edilmiştir. ${ }^{48}$

\section{9-Karum Cibâyeti}

Amasya'ya bağlı olan ve Hatuniye Vakfi'na ait bu cibâyetin gelirleri Maliyeden Müdevver Defterlerde H. 26 Cemaziyelevvel 1000 (M. 10 Mart 1592) tarihli belgede şu şekilde belirtilmiştir: Karum-1 köhne köyü, Gümüşhacıköy kazasına bağlı Burakhacı köyü, Amasya kazasına bağlı Gürköy'ün, rüsum-1 çift, caba, bennak vergileri, beytü'l mal, abd-i 1tk, yave, kaçgun, rüsum-1 tapu-yı zemin, sabuncuhane, resm-i küvvareha ve gayrisi vergileri. Bu cibâyet gelirlerinin Cafer ve Ramazan uhdesinde olduğu ifade edilmiştir. ${ }^{49}$

\subsection{0-Samsun Cibâyeti}

Samsun cibâyeti ile ilgili olarak Maliyeden Müdevver Defterlerde H. 26 Cemaziyelevvel 1000 (M. 10 Mart 1592) tarihli belgede Samsun kazas1 Sabuncuhane mukataasının Bayram adlı kişinin uhdesinde olduğu ifade edilmiştir. Ayrıca çeltik mahsulünden bu seneye dair vakfa herhangi bir nesnenin gelmediği belirtilmiştir. ${ }^{50}$

\section{2-Hamamlar}

İmâret-i Hatuniye Vakfi'na gelir getiren kaynaklardan birisi de hamamlardır. Vakfin hamamlarıyla ilgili Maliyeden Müdevver Defterlerde H. 26 Cemaziyelahir 1000 (M. 9 Nisan 1592) tarihli belgede şu bilgiler verilmektedir: Vakfa bağlı hamam-1 cedidin hamamcı Mahmud, hamam-1 atikin ise hamamc1 Hayreddin uhdesinde olduğu ifade edilmiştir. ${ }^{51} \mathrm{Bu}$ iki hamamdan başka kayıtlarda "imâret hamamı" adlı başka bir hamamın ismi zikredilmektedir.

\section{1-İmâret Hamamı}

İmâret Hamamı'yla ilgili olarak iki adet kayda rastlanmıştır. Bunlardan H. Safer 1029 (M. Ocak/Şubat 1620) tarihli kayda göre Hacı Ali b. Mustafa mahkemede vakfa bağlı İmâret Hamamı'nın tahvilinin (üç yıllık) 60.000 akçeye Piri Çelebi üzerindeyken tahviline 500 akçe daha verip kabul edeceğini beyan etmiştir. ${ }^{52}$

H. Muharrem 1030 (M. Kasım/Aralık 1620) tarihli kayıt, vakfa ait 
hamamın işletilmesindeki problemle ilgilidir. Kayda göre vakfin mütevellisi Süleyman b. Abdullah mahkemede vakfin hamamını üç yıllığına 62.000 akçeye kiralayan Pir Mehmed Çelebi b. Mahmud'un hamamı işletmeyerek boş bıraktığını ve vakfa zarar verdiğini ifade etmiştir. Hamamın kira ücretinde 12.000 akçelik bir indirim yapılarak 1030 Muharrem ayı başından itibaren üç yıllığına yine Pir Mehmed Çelebi'ye kiralandığı belirtilmiştir. ${ }^{53}$

İmâret Hamamı'yla ilgili bir başka kayıt H. Rebiülevvel 1029 (M. Şubat/Mart 1620) tarihlidir. Kayda göre hamamc1 Piri Çelebi b. Mehmed mahkemede Dersaadet Yeniçerilerinden Derviş Beşe b. Hamza Beşe'nin hamam için 64 yük tomruk getirdiğini, karşllığında 160 akçesini kendisine teslim ettiğini ve geri kalanın kendi zimmetinde olduğunu ifade etmiştir. ${ }^{54}$

\section{2-Yeni Hamam}

Vakfın önemli bir gelir kaynağı olan Yeni Hamam'ın 1615'te 21.461 akçe, 1616 'da 21.666 akçe, 1629 'da 6.780 akçe y1llık geliri vardır. ${ }^{55}$ Hamamla ilgili Trabzon mahkeme kayitlarına yansıyan üç dava mevcuttur. H. Recep 1030 (M. Mayıs/Haziran 1621) tarihli kayda göre vakıf mütevellisi İbrahim Ağa mahkemede Yeni Hamam'ın 7 Recep 1030 tarihinden itibaren yıllığ 10.333 akçe olmak üzere üç yıllığına toplam 40.000 akçeye hamamcı Abdullah b. Hamza'ya verildiğini ifade etmiştir. ${ }^{56}$

H. 20 Safer 1031 (M. 4 Ocak 1622) tarihli kayda göre vakfin hamamcis1 Abdullah, hamamın üç yıllığına 40.000 akçe iltizamla kendisindeyken hamamın etrafinda ve mahallede taun olduğunu ve hamama kimsenin gelmediğini beyan ederek tomruk bahasından ve diğerlerinden 40-50 akçelik zararı olduğunu söyleyerek hamamı işletmekten vazgeçtiğini ifade etmiştir. Bunun üzerine Suk-i Sultanî’de duyuru yapıldığı, ancak hamama kimsenin talip olmadığ 1 belirtilmiştir. Sonra vakıf tarafından bir kişinin hamamı işletmesi için tayin edildiği, ancak onun da tahammülü olmadığı görülerek hamamın boş kalmasının da vakfa zarar vereceği düşüncesiyle 1031 yılı Safer başından 3 y1lsonuna kadar tahvili 30.000 akçeye yine Abdullah'a iltizam edildiği ifade edilmiştir. $^{57}$

Yeni Hamam'la ilgili H. Safer 1039 (M. Eylü1/Ekim 1629) tarihli diğer bir kayda göre Dersaadet Yeniçerilerinden Ali, mahkemede Hamam-1 Cedid'in Mehmed uhdesinde y1llığ 7200 akçe kirada iken 800 akçe fazla vererek y1llığını 8.000 akçeye iltizam ettiğini ifade etmiştir. ${ }^{58}$

Yeni Hamam'la ilgili kayitlarda dikkat çeken diğer bir husus ise hama-

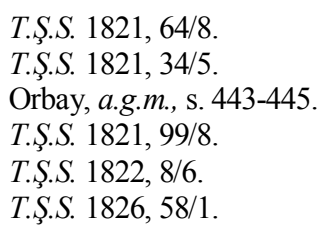


min gelirlerinin mütemadiyen azaldığıdır. Bu durumun başlıca sebeplerinden birinin, şehirde zaman zaman meydana gelen taun hastalığı sebebiyle halkın şehirden uzaklaşması olduğu görülmektedir. Diğer taraftan hamamcıların işletmekten kaçınması ve bu iş için başka taliplerin olmaması da rekabeti azalttığından vakıf, hamam kirasında indirime gitmek mecburiyetinde kalınmıştır. Hamamın gelirini tümüyle kaybetmektense daha düşük bir kira ücreti talep ederek vakfın zararını en aza indirmek amaçlanmıştır.

\section{3-Çifte Hamam}

Vakfa gelir getiren önemli kaynaklardan birisi de Çifte Hamam'dır. Hamamın y1llik geliri 1615 y1lında 14.444, 1616'da 13.633, 1629'da 11.083 akçedir. ${ }^{59}$ Hamamla ilgili H. Safer 1057 (M. Mart/Nisan 1647) tarihli bir kayıtta vakıf mütevellisi Pir Mehmed Çelebi'nin mahkemede Çifte Hamam'1 1057 Safer ayı başlangıcından sene sonuna kadar ayda 800 akçe ile Ömer'e kiraladığ1 belirtilmiştir. ${ }^{60} \mathrm{Bu}$ beyanda, hamamın bu tarihte yılda 9.600 akçe gelir getirdiği anlaşılmaktadır.

H. 8 Rebiülahir 1060 (M. 10 Nisan 1650) tarihli bir kayda göre Çifte Hamam mukataasının daha önce yıllık 9.600 akçeyle Ömer Çelebi'deyken İbrahim adlı kişinin yıllık 10.800 akçe iltizam ile kabul ettiği, aydan aya 900 akçeyi vakfa vereceği belirtilmiştir. Y1lsonuna kadar hamamın İbrahim'in uhdesinde olacağı ifade edilmiştir. ${ }^{61}$

Çifte Hamam'la ilgili H. Zilkade 1060 (M. Ekim/Kasım 1650) tarihli başka bir kayda göre hamamın, 1100 akçe kira ile 1060 Zilkade başından sene sonuna kadar Ahmed'e kiralandığı belirtilmiştir. ${ }^{62} 17$. yüzyıl başlarından itibaren hamamın yıllık gelirinin giderek mütemadiyen azaldığı görülmektedir. Bunda şehirde sık sık meydana gelen veba salgınlarının etkili olduğunu söylemek mümkündür. Ancak 1650'li yıllarda hamam gelirlerinde yeniden bir artış olduğu anlaşılmaktadır.

\section{4-İstanbul Bayezid Camisi Yanındaki Hamam}

Hatuniye İmâreti Vakfi'nın İstanbul'da Bayezid semtinde de bir hamamının olduğu kaynaklardan anlaşılmaktadır. Sultan Bayezid Camii yanındaki yeni hamamın mukataasının senede 75.000 akçe olduğu bilinmektedir. ${ }^{63}$

İstanbul'daki hamamla ilgili kayıtlarda bir adet belgeye rastlanmış olup bu kayıt hamamin tamiri ile ilgilidir. H. Ramazan 1042 evaili (M. Mart 1633) tarihli kayda göre Hatuniye Vakfi'nın İstanbul'da mevcut akarına Dersaadet bevvablarından Hüseyin Bey b. Abdullah'ın mütevelli olduğu ifade edilmiştir.

Orbay, a.g.m., s. 443-445.

T.Ş.S. $1831,32 / 2$.

T.S.S.S. $1831,87 / 9$.

T.S.S. $1831,56 / 12$.

Gökbilgin, a.g.m., s. 238. 
Mütevelli mahkemede hamamın suyolu, kazan ve külhanı'nın tamire ihtiyacı olduğunu, gerekli incelemenin yapılarak vakıf malından tamiri için izin verilmesini talep etmiştir. Mahkemeden Mevlana Ali Efendi ve hassa mimarlarından Ali Çelebi b. Halil ve diğer ehl-i vukuf kişilerle gidilip yerinde inceleme yapılmış ve mütevellinin arz ettiği gibi hamamın tamir edilmesi gerektiğini ifade etmişlerdir. ${ }^{64}$

\section{3-Değirmenler}

Hatuniye Vakfi'na gelir sağlayan kaynaklardan birisi de değirmenlerdir. Mevcut bilgilere göre Hatuniye Vakfı'nın Değirmendere mevkiinde 6 adet değirmeni olduğu anlaşılmaktadır. H. Safer 1037 (M. Ekim/Kasım 1627) tarihli kayda göre bu değirmenlerden 4 adedinin tamire ihtiyac1 olduğu ifade edilmiştir. Değirmenlere Rıdvan ve Lefter adlı kişilerin yıllık 7500 akçe iltizamla talip oldukları ve değirmen taşlarını tamir ederek 1038 Cemaziyelevvel'inin ilk gününden 1039 Receb ayına kadar işletme hakkını aldıkları belirtilmiştir. ${ }^{65}$

\section{4-Boyahane}

Vakfa gelir getiren kaynaklardan birisi de boyahanedir. 1518 tarihli kayıtları ihtiva eden 1 numaralı Timar Zeamet Tevcih Defteri'ne sonradan eklendiği anlaşılan Muharrem 928 (M. Aralık 1521) tarihli bir kayıtta, boyahane mukataasının (7000 akçe) eskiden İmâret-i Hatuniye'ye vakf olunduğu ve bunun geri alınarak sancak beyi gelirlerine ilave edildiği görülmektedir. ${ }^{66}$ Ancak boyahane gelirinin daha sonra tekrar Hatuniye Vakfı'na verildiği anlaşılmaktadır.

Boyahane'nin vakıf muhasebe kayitlarında 1615 yılında yıllık 11.963 akçe, 1629 'da 10.000 akçe gelir getirdiği ifade edilmektedir. Bu kayıtlarda vakfin Samsun'da da bir boyahanesinin olduğu ve yıllık 1500 akçe gelir getirdiği belirtilmektedir. ${ }^{67}$ Trabzon'daki boyahaneyle ilgili, birisi boyahaneye verilen zarar, diğeri de kira artışı olmak üzere mahkemeye yansıyan iki adet kayda rastlanmıştır. H. Şevval 1030 (M. Ağustos/Eylül 1621) tarihli kayıt, boyahaneye hariçten verilen zararın mahkemeye taşınmasıyla ilgilidir. Kayda göre vakıf mütevellisi İbrahim Ağa Aşağı Hisar Mahallesi'ndeki vakfa ait boyahanenin üst katının odalarından Mehmed Beşe adlı kişinin boyahanenin duvarını delip 4 kapı açarak kendi mülküne dâhil ettiğini, ayrıca boyahane üzerindeki kemere de zarar verdiğini (üzerine kilim sererek) beyan etmiş̧ir. Mütevelli ayrıca daha önce boyahaneye zarar vermemesi için etrafına barınak yapıldığını ve Mehmed Beşe'nin mahkeme tarafindan uyarıldığını ifade

BOA, İE.EV, nr. 145., s.1.

T.S.S. 1825, 101/3.

Bostan, a.g.e., s. 397.

Orbay, a.g.m., s. 443, 445. 
etmesine karşın mevcut faaliyetlerine devam ettiğini ifade etmiştir. Mahkeme tarafindan oluşturulan heyetin yaptığı incelemelerde vakıf mütevellisinin beyanının doğru olduğu tespit edilince Mehmet Beşe'nin açtığı kapıları kapatmasının istendiği ve boyahaneye zarar vermemesi konusunda uyarıldığ ifade edilmiştir. ${ }^{68}$

Boyahaneyle ilgili diğer bir kayıt kira artışı ile ilgilidir. H. 1037 Recep ortası (M. Mart 1628) tarihi kayda göre merkezden gönderilen bir hükümde vakfın Aşağı Hisar'daki sabghane (boyahane) sinin senede 9.000 akçe kira ile Arusi ve Neçezar adlı zımmilerde olduğu belirtilmiştir. Boyahaneye Karakaş adlı zımminin senede 10.000 akçe kira ile talip olduğu ancak Arusi ve Neçezar adlı zımmilerin de 10.000 akçe vermeleri üzerine onların uhdesinde kalmasına karar verildiği görülmektedir. ${ }^{69}$

\section{5-Arazi, Bağ, Bina ve Zemin Kiraları}

Trabzon Şeriye Sicilleri'ndeki muhtelif kayıtlarda Hatuniye Vakfi'na ait bir kısım arazi, bağ, bina ve zemin kiralarının da olduğu tespit edilmiştir.

H. Rebiülevvel 1027 (M. Şubat/Mart 1618) tarihli bir kayıtta Tekfur Çayırı Mahallesi'nde bir bina için Murtaza b. Abdullah'ın vakfa ayda 20 akçe kira ödediği anlaşılmaktadır. ${ }^{70}$

Vakıf mütevellisi Mustafa Bey, vakfın Yomra'ya bağlı Hoc köyünde bir kıt'a çayırının olduğunu ifade ederek Feridun b. Abdullah'ın çayırı kullandığını ama kira ödemediğini belirtmiştir. Yapılan inceleme neticesinde Feridun, çayırı kullanmaktan men edilmiştir. Kayıt H. Zilhicce 1041 (M. Haziran/ Temmuz 1632) tarihlidir. ${ }^{71}$ Çayırın on yıldır kullanıldığı belirtilirken vakfa ne kadar kira ödendiğine dair bilgiye rastlanmamıştır.

Aynı tarihli bir başka kayıtta vakfin Kovata köyünde Bali Mandıra denilen yerde bir arazisinin olduğu, bu arazide Murtaza Çelebi'nin ziraat yaptığı ve vakfa senede 20 akçe kira ödediği tespit edilmiştir. ${ }^{72}$

H. 1042 Receb sonu (M. 10 Şubat 1633) tarihli bir kayıtta vakfin Tekfur Çayırı Mahallesi'nde üç bölmeli bir evden senede 2 akçe kira aldığı görülmektedir. Hacı Mustafa b. Halil'in vakfa yılda 2 akçe kirayı ödemeleri şartıyla evi avlusuyla beraber 15 kuruşa Abdullah b. Hızır ve eşi Emine bt. Abdullah'a sattığı belirtilmiştir. ${ }^{73}$

Bir başka kayitta Ahmed Çelebi b. Hasan mahkemede Hatuniye Vakfi'na ayda 4 akçe kira ödeyerek işlettiği iki adet dükkânı İbrahim Beşe'ye 34 adet riyali kuruşa sattığını beyan etmiştir. İbrahim Beşe'nin vakfa ayda 5
T.Ş.S. 1821, 106/2.
T.S.S.S. $1825,99 / 6$.
T.Ş.S. $1820,30 / 1$.
T.S.S. $1824,19 / 3$.
T.S.S. $1824,33 / 5$.
T.Ş.S. 1824, 47/8. 
akçe kira ödeyeceği belirtilmiştir. Kayıt H. Zilkade 1042 (M. Mayıs/Haziran 1633) tarihine aittir. ${ }^{74}$ Dükkânların sınırları belirtilmekle birlikte nerede olduğu ve hangi amaçla kullanıldığı tespit edilememiştir.

H. 12 Receb 1045 (M. 22 Aralık 1635) tarihli bir kayitta Habbaz Kurd b. Süleyman mahkemede Hatuniye Vakfi'na senede 12 akçe kira ödeyerek oturduğu Tekfur Çayırı Mahallesi'ndeki evini, bahçesindeki ağaçlarıyla birlikte Laçin'e 2.040 akçeye sattı̆̆ını ifade etmiştir. ${ }^{75}$

Tekfur Çayırı Mahallesi'nden Zahide bt. Kurd mahkemede aynı mahallede Hatuniye Vakfi'na senede 8 akçe kira ödediği evini ve bir kıt'a bahçesini, 4.000 akçeye Mevlana Mehmed Efendi'ye sattı̆̆ını ifade etmiştir. Kayıt $\mathrm{H}$. Safer 1036 (M. Ekim/Kasım 1626) tarihine aittir. ${ }^{76}$

H. Receb 1040 (M. Şubat/Mart 1631) tarihli bir kayıtta Mustafa Çelebi b. Mehmet mahkemede Gele (sığır) Pazarı'nda Hatuniye Vakfı'na ayda 14 akçe kira ödediği 2 adet buğday mahzenini, 250 adet kuruşa Osman Çelebi b. Yahya Beşe'ye sattığını ifade etmiştir. ${ }^{77}$

Vakfın Bayburt kasabasında da bir bahçeden yıllık 40 akçe kira aldığı H. Rebiülevvel 1053 (M. Mayıs/Haizran 1643) tarihli kayıttan anlaşılmaktadır. Kayda göre Mehmed b. Abdullah Çavuş ve kızkardeşi Rukiyye Hatun mahkemede, Bayburt'ta olan bir bahçeyi (içindeki asma ağaçları, meyveli ve meyvesiz ağaçlarıyla), ev yerleri ve çayırlığıyla birlikte 262,5 kuruşa Çavuş-zade Ali'ye sattıklarını ifade etmişlerdir. Çavuşzade Ali'nin yıllık 40 akçe kirayı vakfa vermeye devam edeceği belirtilmiştir. ${ }^{78}$

\section{Sonuç}

İmâret-i Hatuniye Vakfı sahip olduğu gelirlerle eğitim müesseseleri, ticari müesseseleri, misafirhanesi ve kileriyle şehrin dinî, iktisadî ve toplumsal hayatının en önemli merkezlerden birini teşkil etmektedir. Trabzon şehir merkezinde ve dışında birçok gelire sahip olduğu tespit edilen vakfın 1615 'te 175 personelinin olduğu görülmektedir. Vakfin tam olarak bütün gelirlerini tespit etmek mümkün değildir. Vakfiyesinin mevcut olmayışı, var olan belge ve bilgilerin, vakfın kuruluşundan itibaren tam bir süreklilik arz etmemesi bunda en büyük etkendir. Vakfin en önemli gelirleri araziler (cibâyetler, bağ, bahçe ve zeminler), bedesten, dükkânlar (genelde Sûk-i Sultâni'de), hamamlar (Trabzon şehir merkezinden başka İstanbul'da Sultan Bayezid Camisi yanında bir hamam), değirmenler, boyahane ve bedesten'dir. Vakfin gelirleriyle ilgili ilk bilgilere 16. yüzylla ait Trabzon tahrir defterlerinde rastlanmaktadır. 15181532 tarihleri arasındaki kayıtlara göre vakfın gelirleri yaklaşı olarak 122.000

\footnotetext{
T.Ş.S. $1824,72 / 6$.

T.Ş.S. $1824,73 / 7$.

T.S.S. $1825,58 / 5$.

T.S.S. 1827, 26/1.

T.S.S. 1830, 37/4.
} 
akçe civarındadır. Bunun içerisinde İstanbul'daki hamamın 75.000 akçelik geliri de mevcuttur. 1583 tarihli tahrire göre vakfin gelirlerinde önemli bir değişiklik olmamıştır. 17. yüzyıla gelindiğinde vakfın gelirlerinde önemli bir artış olduğu tespit edilmiştir. Vakfın 1615-1646 yıllarını ihtiva eden muhasebe kayıtları ile ilgili yapılan bir çalışma bunu açık bir şekilde ortaya koymaktadır. Buna göre bir önceki yüzyıla oranla vakfın gelirleri yaklaşık olarak 6 kat artarak 1615'te 782.212 akçe olmuştur. 1615'ten 1646'ya kadar geçen süre içerisinde vakfın gelir ve giderleriyle ilgili verilen tabloda, vakfın gelirlerinin mütemadiyen azaldığı görülmektedir. Bu azalmanın kesin sebeplerini ortaya koymak mümkün olmamakla birlikte genel olarak Osmanlı Devleti'nin 17. yüzyılın başlarından itibaren yaşadığı buhranlar (siyasi, iktisadî, toplumsal vs.) ile 1625 tarihinde Trabzon'a yapılan Rus (Kazak) saldırılarının etkili olduğu söylenebilir. Devletin genel durumunun Trabzon'a ne derecede yansıyıp yansımadığını ortaya koyacak verilerden yoksun olmakla birlikte en azından merkezde meydana gelen ve Osmanlı coğrafyasını etkileyen hadiselerin Trabzon'u da olumsuz etkilediğini ifade etmek mümkündür. Rus (Kazak) saldırılarının şehirde önemli bir zarara yol açtığı, ticaretin kalbi ve vakfın önemli gelir kaynaklarından biri olan bedestenin yandığı görülmektedir. Bedestenle birlikte Hatuniye İmareti'nin ciddi bir zarar gördüğ̈̈, caminin tavanıyla birlikte mutfağının yandığı ve uzun yıllar hizmet veremediği belirtilmiştir. Bu saldırıların sadece şehirdeki vakıf binalarına zarar vermekle kalmayıp şehrin sosyal ve iktisadî yaşantısına önemli bir darbe vurduğu da anlaşılmaktadır.

\section{KAYNAKLAR}

\section{1-Arşiv Belgeleri}

Trabzon Şer 'iye Sicilleri (T.Ş.S.)

Defter no: 1817, 1818, 1819, 1820, 1821, 1822, 1824, 1825, 1826, 1827, 1828, 18230, 1831

Başbakanlık Osmanlı Arşivi Tahrir Defterleri (BOA-TD)

Defter No: 53, 288

Başbakanlık Osmanlı Arşivi Maliyeden Müdevver Defterler (BOA-MAD)

Defter No: 15996

Başbakanlık Osmanlı Arşivi İbnü'l-emin Evkaf Defterleri (BOA- IE.EV)

Defter No: 145

Tapu Kadastro Kuyud-ı Kadime Arşive Tahrir Defterleri (TK. KKA, TD)

Defter No: 29

\section{2-Kitap ve Makaleler}

BERKI, Ali Himmet, Vakfa Dair Yazllan Eserlerle Vakfiye ve Benzeri Vesikalarda Geçen Istılah ve Tabirler, Ankara 1965. 
BOSTAN, Hanefi, XV-XVI. Asırlarda Trabzon Sancă̆ında Sosyal ve İktisadî Hayat, Ankara 2002

GÖKBILLGIN, M. Tayyip, "XVI. Yüzyıl Başlarında Trabzon Livası ve Karadeniz Bölgesi”, Belleten, S: 26, s. 238.

MEHMED ÂŞIK, Menazırü'l Avalim, Haz. Mahmut Ak, Ankara 2007.

ORBAY, Kayhan, "The Impreial Waqf of Hatuniyye in Trabzon 1024-75/16151665", Osmanl Öncesi ve Osmanl Araştırmalart Uluslararast Komitesi XVII. Seтроzуити Bildirileri, Trabzon 2011, s.441-450.

TEKİNDAĞ, Şehabettin, “Trabzon”, İslam Ansiklopedisi, C: 12/1, İstanbul 1997, s. $455-477$.

TOPAL, Zehra, "Hatuniye İmareti Evkafina (Gülbahar Hatun Vakfina) Tahsis Edilen Gelirler”, Akçaabat Yazıları II, Haz. Fethi Gedikli, Trabzon 2004, s. 82-90. 